\title{
IDENTIFIKASI PARAMETER PENENTU KESTABILAN MODEL PERTUMBUHAN LOGISTIK DENGAN WAKTU TUNDA
}

\author{
Rina Ratianingsih ${ }^{1}$ \\ 1Jurusan Matematika FMIPA UNTAD Kampus Bumi Tadulako Tondo Palu
}

\begin{abstract}
Abstrak
Model pertumbuhan logistik dengan waktu tunda digunakanuntuk menggambarkan adanya penurunan dan peningkatan pertumbuhan populasi secara periodik. Pengamatan terhadap kestabilan model tersebut dilakukan linearisasi di sekitar titik kritis dengan metoda pertubasi. Hasil penelitian menunjukkan kaitan antara akar persamaan karakteristik model tersebut dengan waktu tunda. Kaitan tersebut memperlihatkan adanya parameter laju pertumbuhan intrinsik dari populasi sebagai penentu kestabilan model pertumbuhan logistik dengan waktu tunda.

Kata Kunci : Kestabilan, Linearisasi, Model pertumbuhan logistik dengan waktu tunda, Metoda Pertubasi, Ttitik kritis
\end{abstract}

\section{Pendahuluan}

Fenomena pertumbuhan populasi yang populer digambarkan dalam bentuk persamaan logistik senantiasa direvisi sedemikian hingga masalah nyata yang direpresentasikan oleh persamaan tersebut dapat tergambarkan dengan lebih baik. Bila pertumbuhan populasi tidak meninjau adanya penundaan waktu pada proses pertumbuhan populasinya, persamaan logistik masih dapat dipakai. Namun bila fenomena musiman yang ditinjau dengan melibatkan waktu tunda dalam pertumbuhan pupulasi, persamaan logistik perlu direvisi untuk mendapatkan model pertumbuhan logistik dengan waktu tunda. Melalui model tersebut kondisi penurunan dan peningkatan pertumbuhan populasi secara periodik yang menggambarkan penundaan pertumbuhan populasi dapat diungkap dengan baik.

Hal penting yang perlu diidentifikasi dari model pertumbuhan logistik dengan waktu tunda adalah kemunculan parameter penentu dari kestabilan model tersebut. Kestabilan model tersebut diamati dengan linearisasi yakni dengan melakukan pertubasi di sekitar titik kritis. Kestabilan ditentukan dengan mengamati nilai akar persamaan karakteristik yang dikaitkan dengan waktu tunda pertumbuhan populasi. Penurunan yang mengaitkan nilai persamaan karakteristik yang dikaitkan dengan waktu tunda pertumbuhan populasi mengungkap peran penting parameter laju pertumbuhan intrinsik dari populasi dalam menentukan kestabilan model pertumbuhan logistik dengan waktu tunda. Peran tersebut terlihat melalui hubungan tak linier antara laju pertumbuhan intrinsik dari populasi dengan nilai akar persamaan karakteristik. 


\section{Metoda Penelitian}

Pengidentifikasian parameter penentu kestabilan model pertumbuhan logistik dengan waktu tunda dilakukan dengan prosedur sebagai berikut :

1. Meninjau Model pertumbuhan logistik dengan waktu tunda

2. Menentukan titik kritis Model pertumbuhan logistik dengan waktu tunda

3. Melakukan pertubasi di sekitar titik kritis yang memuat waktu tunda

4. Menurunkan kaitan antara waktu tunda dan akar persamaan karakteristik

5. Menurunkan kaitan antara akar persamaan karakteristik dan parameter penentu kestabilan

III. Pembahasan

\section{1 Model pertumbuhan logistik dengan waktu tunda}

Persamaan logistik sederhana tidak dapat digunakan untuk mendeskripsikan pertumbuhan populasi pada kasus adanya keterlambatan (penundaan) pertumbuhan. Untuk itu dilakukan revisi terhadap persamaan logistik sederhana dengan menurunkan model pertumbuhan logistik dengan waktu tunda.

Persamaan pembangun model pertumbuhan logistik dengan waktu tunda dinyatakan dalam (Timuneno, 2008) sebagai berikut :

$$
\frac{d N(t)}{d t}=r N(t)\left[1-\frac{N(t-\tau)}{K}\right]
$$

dengan $N(t)$ adalah banyaknya populasi $N$ pada saat $t$

$r>0$ adalah laju pertumbuhan intrinsik populasi

$N(t-\tau)$ adalah banyaknya populasi $N$ pada saat penundaan

$K$ adalah kapasitas tampung (carrying capacity)

$\tau$ adalah waktu tunda.

\section{2 Titik Kritis Model Pertumbuhan Logistik dengan Waktu Tunda}

Titik kritis model pertumbuhan logistik dengan waktu tunda, yang biasa pula disebut dengan titik kesetimbangan, diperoleh dengan meninjau persamaan (1) pada saat model tersebut tidak mengalami perubahan (Panfilov, 2004) yang dikenal sebagai keadaan zero growth. Hal ini mengakibatkan model memiliki dua titik kritis $N(t)=0$ dan $N(t)=K$. Pengamatan terhadap kestabilan model pertumbuhan logistik dengan waktu tunda dilakukan dengan melakukan linearisasi di sekitar titik kritis dengan metoda pertubasi.

\section{3 Pertubasi di Sekitar Titik-Titik Kritis}

Pada prinsipnya pertubasi di sekitar titik-titik kritis adalah suatu analisis kestabilan linearisasi di sekitar titik kritis dengan metoda pertubasi yang dilakukan dengan memilih parameter pertubasi $\mathcal{E}$ yang sangat kecil $0<\mathcal{E} \ll 1$. Hal ini dapat ditafsirkan bahwa tinjauan 
kestabilan model pertumbuhan logistik dengan waktu tunda dilakukan sangat dekat dengan titiktitik kkritis.

\section{III.3.1 Pertubasi di Sekitar Titik Kritis $N(t)=0$}

Pertubasi di sekitar titik kritis $N(t)=0$ dinyatakan sebagai

$$
N(t)=0+\varepsilon N_{1}(t)
$$

dengan $\varepsilon N_{1}(t)$ adalah perubahan dari titik kritis $N(t)=0$. Substitusi persamaan (2) pada persamaan (1) akan memberikan

$$
\frac{\varepsilon d N_{1}(t)}{d t}=\varepsilon r N_{1}(t)\left[1-\frac{\varepsilon N_{1}(t-\tau)}{K}\right]
$$

Dengan mengabaikan suku tak linier pada persamaan (3) akan diperoleh

$$
\frac{d N_{1}(t)}{d t}=r N_{1}(t)
$$

Mengingat solusi dari persamaan (4) merupakan fungsi eksponensial $N_{1}(t)=c e^{r t}$, dengan $c$ adalah konstanta, maka kestabilan model pertumbuhan logistik dengan waktu tunda di sekitar titik kritis $N(t)=0$ adalah tidak stabil. Hal ini disebabkan laju pertumbuhan intrinsik populasi $r$ senantiasa bernilai positif.

\section{III.3.1 Pertubasi di Sekitar Titik Kritis $N(t)=K$}

Pertubasi di sekitar titik kritis $N(t)=K$ dinyatakan sebagai

$$
N(t)=K+\varepsilon N_{1}(t)
$$

dengan $\varepsilon N_{1}(t)$ adalah perubahan dari titik kritis $N(t)=K$ dimana $\left|\varepsilon N_{1}(t)\right| \leq K$. Substitusi persamaan (5) pada persamaan (1) akan memberikan

$$
\frac{\varepsilon d N_{1}(t)}{d t}=\varepsilon r\left(K+N_{1}(t)\right) \quad\left[1-\frac{K+\varepsilon N_{1}(t-\tau)}{K}\right]
$$

Dengan mengabaikan suku tak linier pada persamaan (3) akan diperoleh

$$
\frac{d N_{1}(t)}{d t}=-r N_{1}(t-\tau)
$$

Dengan mengasumsikan solusi dari persamaan (7) merupakan fungsi eksponensial $N_{1}(t)=c e^{\lambda t}$, dengan $c$ adalah konstanta, dapat diturunkan persamaan karakteristik yang diperoleh dengan melakukan substitusi $N_{1}(t)=c e^{\lambda t}$ pada persamaan (7) sebagai berikut

$$
\lambda+r e^{\lambda \tau}=0
$$

\section{III.4 Kaitan Antara Waktu Tunda dan Akar Persamaan Karakteristik}

Misalkan $\lambda$ pada persamaan (8) dinyatakan dalam bentuk kompleks, yaitu $\lambda=\mu+i v$ dimana $\mu$ dan $v$ secara berturut-turut adalah bagian real dan bagian imajiner dari $\lambda$. Substitusi bentuk kompleks tersebut pada persamaan (8) akan memberikan

$$
\mu+r e^{-\mu \tau} \cos \mu \tau+i\left(v-r e^{-\mu \tau} \sin \mu \tau\right)=0
$$

Sehingga dapat diperoleh bagian real dan bagian imajiner persamaan (9) sebagai berikut

$$
\begin{aligned}
& \mu+r e^{-\mu \tau} \cos \mu \tau=0 \\
& \quad v-r e^{-\mu \tau} \sin \mu \tau=0
\end{aligned}
$$


Mengingat $\cos ^{2} \mu \tau+\sin ^{2} \mu \tau=1$, manipulasi matematika sederhana dari persamaan (10.a) dan persamaan (10.b) akan memberikan relasi berikut

$$
2 \mu \tau=\ln r^{2}-\ln \left(\mu^{2}+v^{2}\right)
$$

Hal ini mengakibatkan substitusi nilai $\tau$ pada persamaan (11) pada persamaan (8) akan memberikan persamaan dalam $\lambda$ sebagai berikut

$$
-\lambda\left(\frac{\ln r^{2}-\ln \left(\mu^{2}+v^{2}\right)}{2 \mu}\right)+\ln \lambda+\ln r=0=f(\lambda)
$$

\section{III.5 Kaitan Antara Akar Persamaan Karakteristik dan Parameter Penentu Kestabilan}

Apabila kita perhatikan kembali persamaan (12) kita dapat menyimpulkan bahwa terdapat kaitan antara akar persamaan tersebut, yakni semua nilai $\lambda$ yang memenuhi $f(\lambda)=0$, dengan laju pertumbuhan intrinsik $r$. Hal ini disebabkan $\left(\mu^{2}+v^{2}\right)$ tidak lain adalah norm dari akar persamaan karakteristik $\lambda$ itu sendiri. Dengan demikian dapat diperoleh kaitan antara akar persamaan karakteristik $\lambda$ dan laju pertumbuhan intrinsik $r$ sebagai berikut

$$
-\lambda\left(\left(\ln r^{\wedge} 2-\ln \|\lambda\|\right) / 2 \mu\right)+\ln \lambda+\ln r=0
$$

Kaitan secara eksplisit antara akar persamaan karakteristik $\lambda$ dan laju pertumbuhan intrinsik $r$ diperoleh dengan menyelesaikan persamaan (13). Untuk suatu nilai laju pertumbuhan intrinsik $r$ yang diberikan dapat ditentukan nilai akar persamaan karakteristik $\lambda$ dengan cara menentukan akar persamaan tak linier dalam variabel $\lambda$. Pengamatan nilai akar persamaan karakteristik $\lambda$ yang diperoleh dapat digunakan sebagai indikator kestabilan model pertumbuhan logistik dengan waktu tunda. Bila bagian real dari akar persamaan karakteristik $\lambda$ yang diperoleh bernilai negative maka pertumbuhan populasi akan stabil, dan bila bagian real dari akar persamaan karakteristik $\lambda$ yang diperoleh bernilai positif maka pertumbuhan populasi akan tidak stabil. Dengan demikian nilai laju pertumbuhan intrinsik $r$ merupakan parameter penentu kestabilan model pertumbuhan logistik dengan waktu tunda.

Kaitan secara eksplisit dapat diperoleh dengan bantuan perangkat lunak matematika MAPLE 12 dengan menentukan solusi persamaan (12) dalam variabel $\lambda$ dan diperoleh

$$
\lambda=\frac{2 \mu \text { LambertW }\left(\frac{1}{2} \frac{\ln \left(\frac{\mu^{2}+v^{2}}{r^{2}}\right)}{\mu r}\right)}{\ln \left(\frac{\mu^{2}+v^{2}}{r^{2}}\right)}
$$

dimana fungsi Lambert $W$ adalah fungsi yang memenuhi LambertW $(x){ }^{*} \exp (\operatorname{LambertW}(x))=x$.

\section{III.5 Identifikasi Penundaan Pertumbuhan Populasi Secara Periodik pada Model Pertumbuhan Logistik dengan Waktu Tunda}

Apabila kita perhatikan kembali persamaan (11), fenomena pertumbuhan populasi tidak akan muncul untuk nilai $\tau=0$. Hal ini disebabkan untuk nilai $\lambda$ tersebut akan 
mengakibatkan persamaan (8) menjadi $\lambda+r e^{-\lambda .0}=0$ sehingga diperoleh nilai persamaan karakteristik $\lambda$ sebagai berikut

$$
\lambda+r=0
$$

Nilai $\lambda$ pada persamaan (15) tidak menampakkan adanya kaitan antara nilai akar persamaan karakteristik $\lambda$ dan waktu tunda. Dengan demikian pada nilai $\tau=0$ tidak terjadi penundaan pertumbuhan populasi.

Identifikasi kemunculan waktu tunda diperoleh dengan mengamati perubahan kestabilan solusi model pertumbuhan logistik dengan waktu tunda yang ditentukan oleh nlai bagian real dari akar persamaan karakteristik $\lambda$. Perlu diperhatikan bahwa $\operatorname{Re}(\lambda)<0$ akan memberikan solusi model pertumbuhan logistik dengan waktu tunda yang stabil, sedangkan $\operatorname{Re}(\lambda)>0$ akan memberikan solusi model pertumbuhan logistik dengan waktu tunda yang tidak stabil. Hal ini menjadikan nilai $\operatorname{Re}(\lambda)=\mu_{0}=0$ sebagai batas kestabilan model pertumbuhan logistik dengan waktu tunda.

Pengamatan terhadap nilai $\mu_{0}=0$ pada persamaan (11) akan memberikan

$$
r=v
$$

Substitusi nilai $r$ dalam persamaan (16) pada persamaan (10.b) akan memberikan

$$
v \tau=\frac{\pi}{2}+2 k \pi, \quad k=0,1,2,3, \ldots
$$

Substitusi kembali nilai $v$ pada persamaan (16) pada persamaan (17) akan memberikan

$$
\tau=\frac{\pi}{2 r}+2 k \pi=\frac{\pi}{2 r}(1+4 k), \quad k=0,1,2,3, \ldots
$$

Persamaan (18) menunjukkan bahwa nilai nilai-nilai $\tau=\frac{\pi}{2 r}, \frac{5 \pi}{2 r}, \frac{9 \pi}{2 r}, \ldots$ populasi mengalami penundaan pertumbuhan secara periodik.

\section{Kesimpulan}

Fenomena terjadinya penundaan secara periodik pada pertumbuhan suatu populasi dapat direpresentasikan dengan baik oleh model pertumbuhan populasi dengan waktu tunda. Identifikasi terhadap kestabilan model tersebut menunjukkan adanya peran penting dari parameter laju pertumbuhan intrinsik $r$ sebagai penentu kestabilan model pertumbuhan populasi dengan waktu tunda. Hal ini disebabkan adanya kaitan antara akar persamaan karakteristik $\lambda$ dengan waktu tunda $\tau$ dan kaitan antara kaitan antara akar persamaan karakteristik $\lambda$ dengan laju pertumbuhan intrinsik $r$ sebagai penentu kestabilan model tersebut.

\section{Daftar Pustaka}

1. Boyce, W. E., and Richard, C. D, 1996, Elementary Differential Equations and Boundary Value Problems, Sixth Edition, Wiley, Singapore.

2. Kartono, 2001, Maple untuk Persamaan Diferensial, Semarang 
3. Lin Y., and Stadherr, M.A., 2005, Global Optimization for Parameter Estimation in

Dynamic

System,

http://aiche.confex.com/aiche/2005/techprogram/P15752.HTM, diakses 1 Oktober 2010.

4. Okmaniar, 2011, Mengkaji Kestabilan Titik Kritis Model Pertumbuhan Logistik dengan Waktu Tunda Melalui Kurva Parameter, UNTAD, Palu.

5. Panfilov, A., 2004, qualitative Analysis of Differential Equations, Utrecht University, Utrecht.

6. Purnomo, Kosala, D., 2000, Model Pertumbuhan Populasi dengan Memidifikasi Model Pertumbuhan Logistik, Majalah Matematika dan Statistik Universitas Jember, Vol(1):21-29,Jember.

7. Timuneno, H. M., Heri Soelistyo Utomo, R., Widowati, 2008, Model Pertumbuhan Populasi dengan Waktu Tunda, Jurnal Matematika : Vol (11) : 43-51, Universitas Negeri Semarang, http://ejournal.undip.ac.id/index.php/matematika/article/view/395/271, diakses 5 Juli 2010. 